\title{
A Note on Senatorial Consideration of
}

\section{Supreme Court Nominees}

\author{
Charles L. Black, Jr. $†$
}

If a President should desire, and if chance should give him the opportunity, to change entirely the character of the Supreme Court, shaping it after his own political image, nothing would stand in his way except the United States Senate. Few constitutional questions are then of more moment than the question whether a Senator properly may, or even at some times in duty must, vote against a nominee to that Court, on the ground that the nominee holds views which, when transposed into judicial decisions, are likely, in the Senator's judgment, to be very bad for the country. It is the purpose of this piece to open discussion of this question; I shall make no pretense of exhausting that discussion, for my own researches have not proceeded far enough to enable me to make that pretense. ${ }^{1}$ I shall, however, open the discussion by taking, strongly, the position that a Senator, voting on a presidential nomination to the Court, not only may but generally ought to vote in the negative, if he firmly believes, on reasonable grounds, that the nominee's views on the large issues of the day will make it harmful to the country for him to sit and vote on the Court, and that, on the other hand, no Senator is obligated simply to follow the President's lead in this regard, or can rightly discharge his own duty by so doing.

I will open with two prefatory observations.

First, it has been a very long time since anybody who thought about the subject to any effect has been possessed by the illusion that a judge's judicial work is not influenced and formed by his whole lifeview, by his economic and political comprehensions, and by his sense, sharp or

+ Henry R. Luce Professor of Jurisprudence, Yale University. BA. 1935, M.A. 1938, University of Texas; LL.B. 1943, Yale.

1. I shall not provide this discussion with an claborate footnote apparatus. I am sorry to say that I cannot acknowledge debt, for I am writing from my mind; experience teaches that, when one does this, one unconsciously draws on much reading consciously forgotten; for all such obligations unwittingly incurred I give thanks. I have had the benefit of discussion of many of the points made herein with students at the Yale Law School, of whom I specifically recollect Donald Paulding Irwin; I have also had the benefit of talking to him about the piece after it was written.

HARRIS, THE ADIICE AND CONSENT OF THE SENATE (1953) came to my attention and hands after the present piece had gone to the printer. This excellent and full account of the entire function would doubtless have fleshed out my own thoughts, but I sce nothing in the book that would make me alter the position taken here, and I hope a single.shot thesis like the present may be useful. 
vague, of where justice lies in respect of the great questions of his time. The loci classici for this insight, now a platitude, are in such writers as Oliver Wendell Holmes, Jr., Felix Frankfurter, and Learned Hand. It would be hard to find a well-regarded modern thinker who asserted the contrary. The things which I contend are both proper and indispensable for a Senator's consideration, if he would fully discharge his duty, are things that have definitely to do with the performance of the judicial function. The factors I contend are for the Senator's weighing are factors that go into composing the quality of a judge. The contention that they may not properly be considered therefore amounts to the contention that some things which make a good or bad judge may be considered-unless the Senator is to consider nothing-while others may not.

Secondly, a certain paradox would be involved in a negative answer to the question I have put. For those considerations which I contend are proper for the Senator are considerations which certainly, notoriously, play (and always have played) a large, often a crucial, role in the President's choice of his nominee; the assertion, therefore, that they should play no part in the Senator's decision amounts to an assertion that the authority that must "advise and consent" to a nomination ought not to be guided by considerations which are hugely important in the making of the nomination. One has to ask, "Why"? I am not sug. gesting now that there can be no answer; I only say that an answer must be given. In the normal case, he who lies under the obligation of making up his mind whether to advise and consent to a step considers the same things that go into the decision whether to take that step. In the normal case, if he does not do this, he is derelict in his duty.

I have called this a constitutional question, and it is that (though it could never reach a court), for it is a question about the allocation of power and responsibility in government. It is natural, then, for American lawyers to look first at the applicable text, for what light it may cast. What expectation seems to be projected by the words, "The Pres" ident ... shall nominate, and by and with the Advice and Consent of the Senate shall appoint ... Judges of the Supreme Court ...." Do Do these words suggest a rubber-stamp function, confined to screening out proven malefactors? I submit that they do not. I submit that the word "advice," unless its meaning has radically changed since 1787, makes next to impossible that conclusion.

2. U.S. Const. art. II, § 2, cl. 2. 
Procedurally, the stage of "advice" has been short-circuited. 3 Nobody could keep the President from doing that, for obvious practical reasons. But why should this procedural short-circuiting have any effect on the substance so strongly suggested by the word "advice"? He who merely consents might do so perfunctorily, though that is not a necessary but merely a possible gloss. He who advises gives or withholds his advice on the basis of all the relevant considerations bearing on decision. Am I wrong about this usage? Can you conceive of sound "advice" which is given by an advisor who has deliberately barred himself from considering some of the things that the person he is advising ought to consider, and does consider? If not, then can the Presidents, by their unreviewable short-circuiting of the "advice" stage, magically have caused to vanish the Senate's responsibility to consider what it must surely consider in "advising"? Or is it not more reasonable to say that, in deciding upon his vote at the single point now left him, every Senator ought to consider everything he would have considered if, procedurally, he were "advising"? Does not the word "advice" permanently and inescapably define the scope of Senatorial consideration?

It is characteristic of our legal culture both to insist upon the textual reference-point, and to be impatient when much is made of it, so I will leave what $I$ have said about this to the reader's consideration, and pass on to ask whether there is anything else in the Constitution itself which compels or suggests a restriction of Senatorial consideration to a few rather than to all of the factors which go to making a good judge. I say there is not; I do not know what it would be. The President has to concur in legislation, unless his veto be overridden. The Senate has to concur in judicial nominations. That is the simple plan. Nothing anywhere suggests that some duty rests on the Senator to vote for a nomination he thinks unwise, any more than that a duty rests on the President to sign bills he thinks unwise.

Is there something, then, in the whole structure of the situation, something unwritten, that makes it the duty of a Senator to vote for a man whose views on great questions the Senator believes to make him dangerous as a judge? I think there is not, and I believe I can best make my point by a contrast. The Senate has to confirm-advise and consent

3. Even this short-circuiting is not complete. First, the President's "appointment," after the Senate's action, is still voluntary (Marbury v. Mfadison, 5 U.S. (1 Cranch) 137, 155 (1803)), so that in a sense the action of the Senate even under setted practice may be looked on as only "advisory" with respect to a step from which the President may still withdraw. Secondly, nominations are occasionally withdrawn after public indications of Senate sentiment (and probable action) which may be thought to amount to "advice" 
to-nominations to posts in the executive department, including cabinet posts. Here, I think, there is a clear structural reason for a Senator's letting the President have pretty much anybody he wants, and certainly for letting him have people of any political views that appeal to him. These are his people; they are to work with him. Wisdom and fairness would give him great latitude, if strict constitutional obligation would not.

Just the reverse, just exactly the reverse, is true of the jucliciary. The judges are not the President's people. God forbid! They are not to work with him or for him. They are to be as independent of him as they are of the Senate, neither more nor less. Insofar as their policy orientations are material-and, as I have said above, these can no longer be regarded as immaterial by anybody who wants to be taken seriously, and are certainly not regarded as immaterial by the President-it is just as important that the Senate think them not harmful as that the President think them not harmful. If this is not true, why is it not? I confess here I cannot so much as anticipate a rational argument to which to address a rebuttal.

I can, however, offer one further argument tending in the same direction. The Supreme Court is a body of great power. Once on the Court, a Justice wields that porver without democratic check. This is as it should be. But is it not wise, before that power is put in his hands for life, that a nominee be screened by the democracy in the fullest manner possible, rather than in the narrowest manner possible, under the Constitution? $\mathrm{He}$ is appointed by the President (when the President is acting at his best) because the President believes his worldview will be good for the country, as reflected in his judicial performance. The Constitution certainly permits, if it does not compel, the taking of a second opinion on this crucial question, from a body just as responsible to the electorate, and just as close to the electorate, as is the President. Is it not wisdom to take that second opinion in all fullness of scope? If not, again, why not? If so, on the other hand, then the Senator's duty is to vote on his whole estimate of the nominee, for that is what constitutes the taking of the second opinion.

Textual considerations, then, and high-political considerations, seem to me strongly to thrust toward the conclusion that a Senator both may and ought to consider the lifeview and philosophy of a nominee, before casting his vote. Is there anything definite in history tending in the contrary direction?

In the Constitutional Convention, there was much support for appointment of judges by the Senate alone-a mode which was approved 
on July $21,1787,4$ and was carried through into the draft of the Committee of Detail. 5 The change to the present mode came on September 4 th, in the report of the Committee of Eleven ${ }^{0}$ and was agreed to nem. con. on September 7 th. ${ }^{7}$ This last vote must have meant that those who wanted appointment by the Senate alone-and in some cases by the whole Congress-were satisfied that a compromise had been reached, and did not think the legislative part in the process had been reduced to the minimum. The whole process, to me, suggests the very reverse of the idea that the Senate is to have a confined role.

I have not reread every word of The Federalist for this opening-gun piece, but I quote here what seem to be the most apposite passages, from Numbers 76 and 77:

But might not his nomination be overruled? I grant it might, yet this could only be to make place for another nomination by himself. The person ultimately appointed must be the object of his preference, though perhaps not in the first degree. It is also not very probable that his nomination would often be overruled. The Senate could not be tempted, by the preference they might feel to another, to reject the one proposed; because they could not assure themselves, that the person they might wish would be brought forward by a second or by any subsequent nomination. They could not even be certain, that a future nomination would present a candidate in any degree more acceptable to them; and as their dissent might cast a kind of stigma upon the individual rejected, and might have the appearance of a reflection upon the judgment of the chief magistrate, it is not likely that their sanction would often be refused, where there were not special and strong reasons for the refusal.

To what purpose then require the cooperation of the Senate? I answer, that the necessity of their concurrence would have a powerful, though, in general, a silent operation. It would be an excellent check upon a spirit of favoritism in the President, and would tend greatly to prevent the appointment of unfit characters from State prejudice, from family connection, from personal attachment, or from a view to popularity. In addition to this, it would be an efficacious source of stability in the administration.

It will readily be comprehended, that a man who had himself the sole disposition of offices, would be governed much more by his private inclinations and interests, than when he was bound to submit the propriety of his choice to the discussion and determination of a different and independent body, and that body an

4. 2 ReCORDS OF THE FEDERAL Convention of 1787, at 83 (AT. Farrand cd. 1911).

5. Id. at $132,146,155,169,183$.

6. Id. at 498 .

7. Id. at 539 . 
entire branch of the legislature. The possibility of rejection would be a strong motive to care in proposing. The danger to his own reputation, and, in the case of an elective magistrate, to his political existence, from betraying a spirit of favoritism, or an unbecoming pursuit of popularity, to the observation of a body whose opinion would have great weight in forming that of the public, could not fail to operate as a barrier to the one and to the other. He would be both ashamed and afraid to bring forward, for the most distinguished or lucrative stations, candidates who had no other merit than that of coming from the same State to which he particularly belonged, or of being in some way or other personally allied to him, or of possessing the necessary insignificance and pliancy to render them the obsequious instruments of his pleasure. ${ }^{8}$

If it be said they might sometimes gratify him by an acquiescence in a favorite choice, when public motives might dictate a different conduct, I answer, that the instances in which the President could be personally interested in the result, would be too few to admit of his being materially affected by the compliances of the Senate. The power which can originate the disposition of honors and emoluments, is more likely to attract than to be attracted by the power which can merely obstruct their course. If by influencing the President be meant restraining him, this is precisely what must have been intended [emphasis supplied]. And it has been shown that the restraint would be salutary, at the same time that it would not be such as to destroy a single advantage to be looked for from the uncontrolled agency of that Magistrate. The right of nomination would produce all the good of that of appointment, and would in a great measure avoid its evils. ${ }^{0}$

I cannot see, in these passages, any hint that the Senators may not or ought not, in voting on a nominee, take into account anything that they, as serious and public-spirited men, think to bear on the wisdom of the appointment. It is predicted, as a mere probability, that Presidential nominations will not often be "overruled." But "special and strong reasons," thus generally characterized, are to suffice. Is a Senator's belief that a nominee holds skewed and purblind views on social justice not a "special and strong reason"? Is it not as "special and strong" as a Senator's belief that an appointment has been made "from a view to popularity"-a reason which by clear implication is to suffice as support for a negative vote? If there is anything in The Federalist Papers neutralizing this inference, I should be glad to see it.

8. The Federalist No. 76, at 494-95 (Modern Library 1937) (Alexander Hitullton), 9. Id. No. 77, at 498 (Alexander Hamilton). 
When we turn to history, the record is, as always, confusing and multifarious. One can say with confidence, however, that a good many nominations have been rejected by the Senate for repugnancy of the nominee's views on great issues, or for mediocrity, or for other reasons no more involving moral turpitude than these. Jeremiah Sullivan Black, an eminent lawyer and judge, seems to have been rejected in 1861 because of his views on slavery and secession. ${ }^{10} \mathrm{John} \mathrm{J}$. Crittenden was refused confirmation in 1829 on strictly partisan grounds. ${ }^{11}$ Wolcott was rejected partly on political grounds, and partly on grounds of competence, in 1811.12 There is the celebrated Parker case of this century. ${ }^{13}$ The perusal of Warren ${ }^{14}$ will multiply instances.

I am very far from undertaking any defense of each of these actions severally. I am not writing about the wisdom, on the merits, of particular votes, but of the claim to historical authenticity of the supposed "tradition" of the Senators' refraining from taking into account a very wide range of factors, from which the nominees' views on great public questions cannot, except arbitrarily, be excluded. Such a "tradition," if it exists, exists somewhere else than in recorded history. Of course, all these instances may be dismissed as improprieties, but then one must go on and say why it is improper for the Senate, and each Senator, to ask himself, before he votes, every question which heavily bears on the issue whether the nominee's sitting on the Court will be good for the country.

I submit that this "tradition" is just a part of the twentieth-century mystique about the Presidency. That mystique, having led us into disastrous undeclared war, is surely due for reexamination. I do not suggest that it can be or should be totally rejected. I am writing here only about a little part of its consequences.

To me, there is just no reason at all for a Senator's not voting, in regard to confirmation of a Supreme Court nominee, on the basis of a full and unrestricted review, not embarrassed by any presumption, of the nominee's fitness for the office. In a world that knows that a man's social philosophy shapes his judicial behavior, that philosophy is a factor in his fitness. If it is a philosophy the Senator thinks will make a judge whose service on the Bench will hurt the country, then the

10. 2 C. Warren, The Supreme Court in United States History 304 (rev. ed. 192G).

11. 1 id. at 704 .

12. Id. at 413 .

13. L. Pfeffer, This Honorable Court, a History of the Untred States Supresie Court 288 (1965).

14. C. WArren, The Supreme Court in Untted States History (rev. ed. 1920). 
Senator can do right only by treating this judgment of his, unencumbered by deference to the President's, as a satisfactory basis in itself for a negative vote. I have as yet seen nothing textual, nothing structural, nothing prudential, nothing historical, that tells against this view. Will someone please enlighten me? 